\title{
T-cell epitopes of the major peach allergen, Pru p 3: Identification and differential T-cell response of peach-allergic and non-allergic subjects
}

\author{
Leticia Tordesillas , Javier Cuesta-Herranz , Miguel Gonzalez-Muñoz , Luis F. Pacios , Esther Compés , \\ Belen Garcia-Carrasco , Rosa Sanchez-Monge , Gabriel Salcedo , Araceli Diaz-Perales
}

Unidad de Bioquimica, Departamento de Biotecnologia, E.TS. ingenieros Agtonomos, UPM, Madrid, Spain Servicio de Alergia, Flindacion jimernez Diaz, Madid, Spain

Servicio de inmunologia, Hospital de Salud Carlos III, Madid, Spain

unidad de Quimica y Bioguimica, Departamento de Bioteonologia, E.TS. Ingenieros de Montes, UPM, Madrid, Spain

Keywords:

Lipid transfer protein

T-cell epitope

Peptide immunotherapy

Plant tood alletgy

Peach

Pru 3

\begin{abstract}
A B S T R A C T
Lipid transfer proteins (LTPs), particularly peach Pru p 3, are the most relevant plant food allergens in the South of Europe, and, therefore, their allergic properties have been extensively studied. However, neither T-cell epitopes nor their effect on the patients' T-cell response has been investigated in any member of the LTP panallergen family. The objective of the present study was to map the major T-cell epitopes of PTu p 3, as well as to evaluate their induced $T$-cell response in peach-allergic versus control subjects. Thus, peripheral blood mononuclear cells (PBMCs) from 18 peach-allergic patients and Pru p 3-specific T-cell lines (TCLs) from 9 of them were cultured with Pru $\mathrm{p} 3$ and with a panel of 17 derived peptides (10-mer overlapping in 5 amino acids representing the full sequence of Pru p 3). Proliferation in $\mathbf{5}$-day assays was carried out via tritiated-thymidine incorporation, while IL4 and IFNy production was assessed via sandwich enzymelinked immunosorbent tests (ELISA) of TCL culture supernatants. The results were compared to those obtained from 10 non-peach allergic control volunteers. Two consecutive peptides showed the highest activation capacity. About 74\% of PBMCs and TCLs recognized them, forming a single T-epitope: Pru P $3_{65-80}$. Additionally, other specific T-cell epitopes were observed. Pru p $3_{25-35}$ was detected by more than $60 \%$ of TCLs from peach-allergic patients, and Pru p $345-55$ only activated PBMCs from control subjects. Interestingly. TCLs from patients were associated with a Th2-type, whereas control TCLs presented a Th1type cytokine response. The major immunogenic T-cell epitope identified in Pru p 3, Pru p 365-80, is a good candidate to develop new vaccines for hypersensitivity reactions associated with LTP allergens from Rosaceae fruits.
\end{abstract}

\section{Introduction}

Peach is the major plant food involved in lgE-mediated reactions affecting the adult population from Southern European countries (Cuesta-Herranz et al., 1998; Kanny et al., 2001; Fernandez-Rivas et al., 2003). Accordingly. Pru p 3, its major allergen and lipid transfer protein (LTP) (Sanchez-Monge et al., 1999; Salcedo et al., 2007), has been identified as the food allergen showing the highest prevalence of sensitization (positive-specific $\lg E$ ) in the Spanish adult population with plant food allergy (Red Vegetalia, Instituto de Salud Carlos [Il, MSC, Spain; unpublished results). Clinically re]evant peach allergy is associated to Pru p 3 (Fernandez-Rivas et al., 2003), and this allergen also mediates cross-reactions between peach and some pollens, such as Artemisia vulgaris (Lombardero et al., 2004: Salcedo et al., 2007; Zuidmeer and van Ree, 2007) and Platanus acerifolia (Laurer et al., 2007), a relevant issue considering that most peach-allergic patients (around $80 \%$ in Spain) also suffer pollinosis (Cuesta-Herranz et al., 1999).

Plant non-specific LTPs (type 1) are 9 kDa basic polypeptides, with a very compact and conserved 3-D structure stabilized by four disulphide bridges (Salcedo et al., 2007). This protein family is widely distributed throughout the plant kingdom, and has been related to defence mechanisms against plant pathogens and abiotic 
stress (Salcedo et al., 2007). Allergenic LTPs are highly resistant to protease digestion and heat treatments. They are usually associated to severe and systemic clinical symptoms and can be primary sensitizers by ingestion. They are also the main allergens of several fruits, vegetables and nuts in the Mediterranean area (Salcedo et al., 2007). Altogether, these characteristics have led to propose LTPs, particularly Pru p 3, as a model of true food allergens (van Ree, 2002; Salcedo et al., 2007).

Cross-reactivity between Pru p 3 and other plant food LTP allergens has been demonstrated (Diaz-Perales et al., 2000), and a recombinant form with immunological equivalence to natural Pru p 3 has been developed to be used in allergen component-based in vitro diagnosis (Diaz-Perales et al., 2003). Furthermore, both sequential and conformational IgE epitopes have been located in the 3-D structure of Pru p 3, and a potential hypoallergenic variant has been produced by site-directed mutagenesis (Garcia-Casado et al., 2003: Pacios et al., 2008). In contrast, no T-cell epitope of either Pru $\mathrm{p} 3$ or any other allergenic LTP from plant foods has been identified so far.

In spite of the high number of cross-reactions which have been related with peach (over 20 ), the only prescription for affected patients is the non-consumption of the foods involved. The scarce knowledge of food allergy mechanism prevents the development of new strategies for immunotherapy. Therefore, further research work is necessary to improve the diagnosis and treatment of this kind of hypersensitivity. The identification of major T-cell epitopes of the main plant food allergens is crucial for the development of T-cell targeted strategies (Glaspole et al., 2005). In the present study, PBMCs and TCLs from peach-allergic patients and nonpeach-allergic controls were stimulated with the allergen and with a set of overlapping peptides representing the full sequence of Pru p 3. The induced proliferation responses and cytokine production were measured.

\section{Materials and methods}

\subsection{Peach-allergic patients and non-peach-allergic controls}

Peripheral blood from 18 peach-allergic patients sensitised to Pru p 3 and from 10 control volunteers non-allergic to peach was collected for this study. Patients were selected at the Servicio de Alergia, Fundacion Jimenez Diaz (Madrid) based on the following criteria: (1) a convincing clinical history of allergic reactions after peach ingestion. The presence of peach allergy was further confirmed in all selected patients by an open challenge test to peach, following a method previously described (Cuesta-Herranz et al., 1998); (2) a positive skin prick test (SPT; EAACl, subcomittee of Skin Tests Allergen Standarization, 1989) response to a commercial peach extract (ALK-Abello, Madrid, Spain); and (3) sensitization to Pru p 3, ascertained by a positive SPT response to purified natural Pru p $3(20 \mu \mathrm{g} / \mathrm{ml})$ and a significant specific lgE level to recombinant Pru p $3(5 \mu \mathrm{g} / \mathrm{ml}$ in solid phase; range: $0.304-2.757$ OD units; cut-off value: mean $+3 \times$ S.D. $=0.189$ to bovine serum albumin used as negative control) determined by an ELISA assay as previously reported (Diaz-Perales et al., 2003). Fourteen out of the 18 selected patients showed oral allergy syndrome (OAS), 3 had systemic reactions and associated OAS and 1 had exclusively systemic symptoms. According to their lack of reaction after peach ingestion, a negative SPT to a commercial peach extract (ALK-Abello, Madrid, Spain), and non-sensitized to Pru p 3, the 10 non-allergic to peach control volunteers confirmed non-IgE to recombinant Pru p 3 (range: 0.000-0.088 OD units), determined by the ELISA assay (see above). Seven out of the 10 control subjects were non-atopic, 2 were allergic to grass (Phleum pratense) pollen and 1 was allergic to wasp venom.
A written IFNormed consent was obtained from both patients and controls and the study was approved by the Ethics Committee of Fundacion Jimenez Diaz (Madrid).

\subsection{Purified Pru $p 3$ and synthetic Pru $p$ 3-derived peptides}

Natural Pru $\mathrm{p} 3$ was isolated from peach peel and its recombinant form from cultured supernatants of transformed Pichia pastoris cells as described by Diaz-Perales et al. (2003).

A panel of 17 decapeptides was synthesized by following the amino acid sequence of Pru p 3. Peptides of 10-mer (overlapping in 5 amino acids) were produced by EZBiolabs (Westield, IN, USA). The stock of each peptide was suspended in DMSO $(10 \mathrm{mg} / \mathrm{ml})$, and then diluted to $1 \mathrm{mg} / \mathrm{ml}$ in PBS buffer $(0.1 \mathrm{M}$ sodium phosphate, $0.15 \mathrm{M} \mathrm{NaCl}, \mathrm{pH} 7.4$ ) before added to the cell cultures. DMSO or PBS buffer did not affect the proliferation of PBMC or TCL cultures (data not shown).

\subsection{Proliferation assays with PBMCs}

PBMCs were freshly isolated from $100 \mathrm{ml}$ of blood subjected to density gradient centrifugation on Lymphoprep (Axis-Shield, Oslo, Norway). Cultures were established in triplicate in 96-well plates (Costar, NY, USA) at $5 \times 10^{5}$ cells per well for proliferation analysis in a total volume of $200 \mu$ l of RPMI media (Invitrogen, Paisley, UK), supplemented with $10 \%(\mathrm{v} / \mathrm{v})$ of fetal calf serum (Invitrogen), $0.02 \mathrm{mM}$ mercaptoethanol, $2 \mathrm{mM}$ of glutamine, and $10 \mathrm{mM}$ HEPES, in the presence of $10 \mu \mathrm{g} / \mathrm{ml}$ of Pru p 3 or $1 \mu \mathrm{g} / \mathrm{ml}$ of each peptide, for 5 days at $37^{\circ} \mathrm{C}_{+}$in a $5 \% \mathrm{CO}_{2}$ humidified atmosphere. During the last $16 \mathrm{~h},\left[{ }^{3} \mathrm{H}\right]$-thymidine $(0.5 \mu \mathrm{Ci} /$ well) was added, and the incorporated radioactivity was measured by scintillation counting. The concentrations of Pru p 3 and synthetic peptides were determined by dose-response experiments using PBMCs from two different patients and $0-50 \mu \mathrm{g} / \mathrm{ml}$ of Pru p 3 or each peptide. These concentrations were similar to those previously published for other allergens (Ebner et al., 1995; Zeiler et al., 1999: Jahn-Schmid et al., 2002). Phytohemagglutinin-L from Phaseolus vulgaris (PHA: 1 pg/ml; Roche, Mannheim, Germany) was used as a positive control to evaluate the proliferative response of PBMC cultures.

The stimulation index (SI) was calculated as the ratio between counts of antigen-stimulated cultures and counts without any activator. $\mathrm{ASI} \geq 2$ was considered a positive value for PBMCs.

\subsection{Pru p 3-specific TCLs}

PBMCs ( $2 \times 10^{6}$ cells per well; 24 -well plates) were treated with $10 \mu \mathrm{g} / \mathrm{ml}$ of Pru p 3 in a RPMl supplemented media (see above). After 5 days, a half-volume media was removed and suboptimal doses of rlL2 (10 ng/ml; Biosource, Invitrogen, UK) were added. Cultures were continued for an additional 7 days. On the 12 th day, fresh media supplemented with rIL2 was added in the presence of $10^{5}$ autologous-mitomycin-treated PBMCs. Finally (on the 19th day of culture) Pru p 3-TCLs $\left(5 \times 10^{4}\right.$ cells per well) and their mitomycintreated PBMCs $\left(10^{5}\right.$ cells per well) were seeded in 96 wells. Pru $\mathrm{p}$ $3(10 \mu \mathrm{g} / \mathrm{ml})$ or each peptide $(1 \mu \mathrm{g} / \mathrm{ml})$ were added to the TCL culture in triplicate wells for $48 \mathrm{~h}$. Within the last $16 \mathrm{~h},\left[{ }^{3} \mathrm{H}\right]$-thymidine $(0.5 \mu \mathrm{Ci} /$ well) was added, and the incorporated radioactivity was measured by scintillation counting. The stimulation index was calculated as described above. In this case, a $\mathrm{SI} \geq 3$ was considered a positive value for TCLs.

Before counting, supernatants were recovered to quantify the cytokines (IL4 and IFN $\gamma$ ) by ELISA assays. 


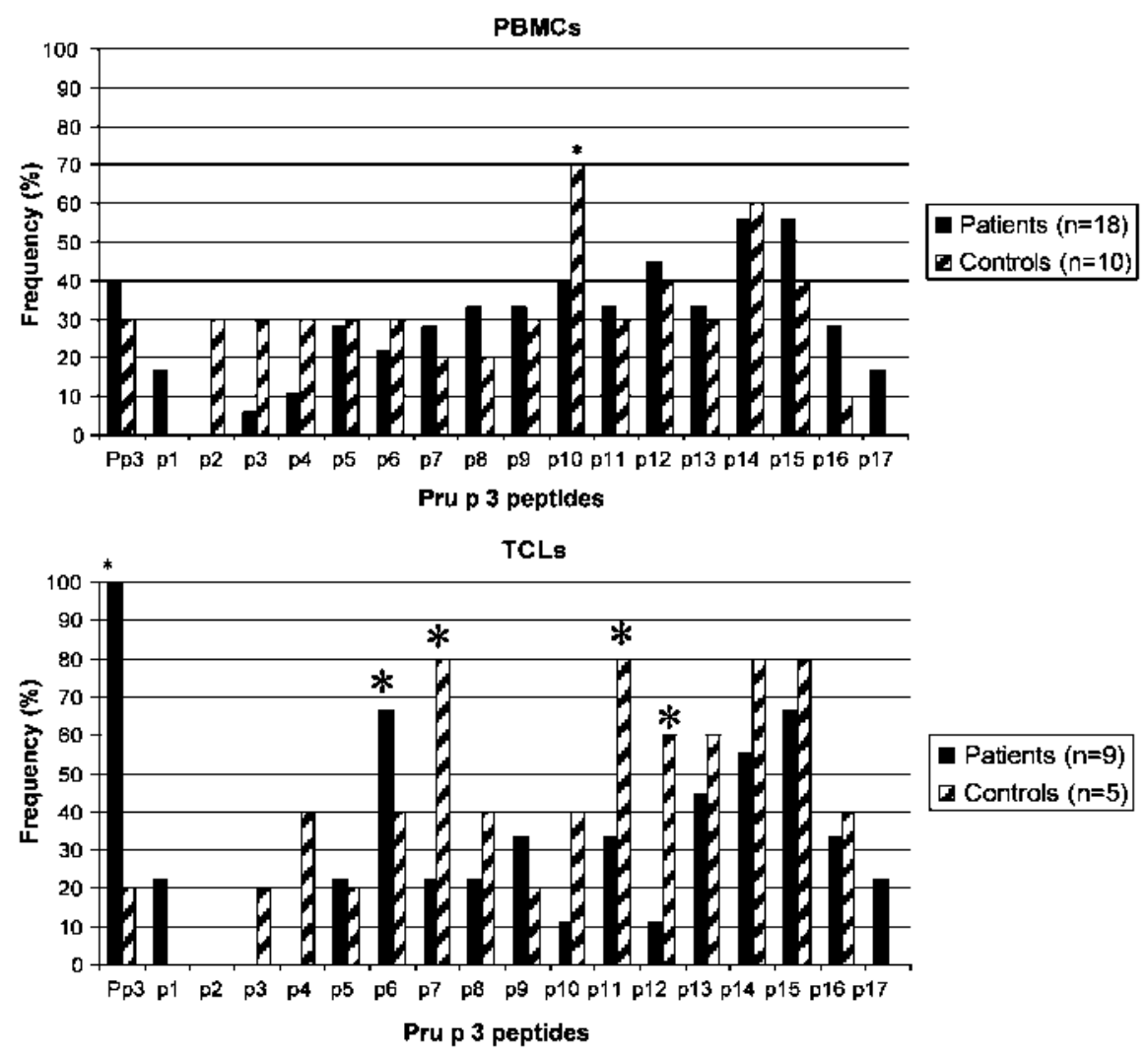

Fig. 1. Frequency (\%) of positive responses of PBMCs and TCLs from patients and control subjects to Pru p 3 (Pp3) and its 17 synthetic derived peptides (p1-p17). Significant differences $(p<0.05)$ between both groups are marked (").

\subsection{Location of T-cell epitopes on the 3-D structure of Pru $p 3$}

Chain A of the X-ray structure, PDB code 2B5S (Pasquato et al., 2006), was used to locate peptides on the three dimensional structure and surface of Pru p 3. Molecular graphics in Fig. 1 were prepared with PyMOL 1.0 (pymol.sourceforge.net).

\subsection{Determination of IL4 and IFNy levels in TCL cultures}

Fifty microliters of TCL-supernatants were used to quantify the cytokine levels by using matched antibody-pairs according to the manufacturer's instructions (sensitive limits: IL4, $0.6 \mathrm{pg} / \mathrm{ml}$; IFN $\gamma$, $2 \mathrm{pg} / \mathrm{ml}$; Immuno Tools, Friesoythe, Germany). Cultures containing TCLs with mitomycin-treated PBMCs alone served as negative controls. IFN $\gamma /$ IL 4 tatios over 10, between 2 and 10 and less than 2 , were respectively considered as Th1-, Th0- and Th2- responses.

\subsection{Phenotypic analysis of TCLS}

To analyze T-cell phenotypes, cells were stained with $20 \mu \mathrm{L}$ of anti-CD4-fluorescein isothiocyanate, anti-CD8 phycoerithrin (PE) and anti-CD3-Cy5-PE reagent mixture (Affinity BioReagents, $\mathrm{CO}$, USA) for $20 \mathrm{~min}$ in the dark ( $300 \times \mathrm{g}, 5 \mathrm{~min}$ ) and washing with PBS, cells were suspended in $300 \mu \mathrm{L}$ PBS buffer, and analyzed in a FACSort flow cytometer with the CellQuest Pro software (BD Biosciences, Erembodegen, Belgium).

\subsection{Statistical analysis}

Proliferative responses (SI) to each antigen (Pru p 3 and each of the derived peptides) of patients and control subjects were compared (Fig. 2) by Mann-Whitney non-parametric $U$-test. Lev- els of IL4 and JFNy in supernatants of TCLs from patients and controls treated with Pru p 3 and each of the 17 derived peptides (joint analysis of the 17 samples; Fig. 3) were compared by Krustal-Wallis one-way nonparametric ANOVA. A level of significance $<5 \%(p<0.05)$ was considered to be significant in both analysis.

\section{Results}

\subsection{T-cell epitope mapping: patients versus controls}

PBMCs from 18 peach-allergic patients sensitized to Pru $\mathrm{p} 3$ and 10 non-peach-allergic controls without Pru p 3 sensitization were cultured in the presence of the complete allergen or each of its 17-derived synthetic peptides. Overall, the proliferative response observed against these antigens were roughly more similar in patients (mean: $9714 \mathrm{cpm}$; range: $2440-23,327 \mathrm{cpm}$; background: $832 \mathrm{cpm}$ ) than in control subjects (mean: 11,325; range: $1331-20,005 \mathrm{cpm}$; background: $1859 \mathrm{cpm}$ ). The PBMC responses were analyzed by comparing the SI obtained with each antigen. The results are summarized in Table 1 and Fig. 2. Pru $\mathrm{p} 3$ activated 7 out of 18 (39\%) and 3 out of 10 (30\%) of PBMCs from patients and controls, respectively, resulted similarly to those reported for other allergens and groups of patients (Glaspole et al., 2005; Tanabe, 2007). A fault in the cultures can be discarded, because commercial phytohemagglutinin (PHA) induced high responses in all PBMCs (mean: 37,787; range: $22,956-89,723 \mathrm{cpm}$; SI range: $27.6-107.8$ ).

PBMCs from patients displayed different responses to the 17derived synthetic peptides. Peptides 14 and 15 triggered the highest rate of activation (positive SI to at least one of them in $72 \%-13$ out of 18 - of PBMCs), being the only one reaching stimulation in more than $50 \%$ of the patients analyzed. Both contiguous peptides can 
(A)
1 ITCGQVSSSIAPCIPYVRGGGAVPPACCNGIRNVNNLARTTPDRQAACNC
51 $60 \quad 70$
so
91
LKQLSASVPGVNPNNAAALPGKCGVSIPYKISASTNCATVK
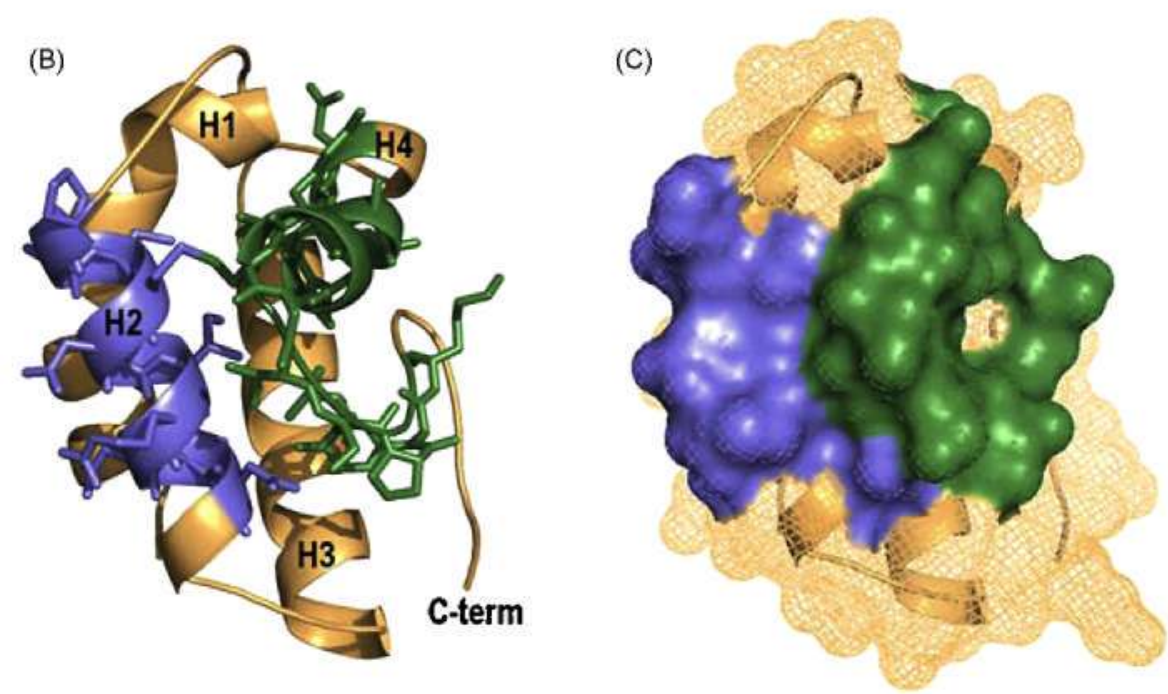

Fig. 2. Frequency $(\%)$ of positive levels of IL4 and IFN $\gamma$ in TCL supernatants from patients and control subjects treated with rPru p 3 or its derived peptides (pooled data of the 17 synthetic peptides). Medians $(\square)$ and S.D.s (bars) were calculated from $n=14$ for Pru $p 3$ and $n=238$ for peptides. Significant differences ( $p<0.05$ ) are indicated $\left({ }^{*}\right)$.

Table 1

Positive responses (stimulation index, SI) of PBMCs and TCIs from peach-allergic patients to purified Pru p 3 and synthetic peptides (1-17) covering its full amino acid sequence. The positive results are remarked by shadowings.

\begin{tabular}{|c|c|c|c|c|c|c|c|c|c|c|c|c|c|c|c|c|c|c|c|c|}
\hline & \multicolumn{20}{|c|}{ PBMCs } \\
\hline & Patients no. & 1 & 2 & 3 & 4 & 5 & 6 & 7 & 8 & 9 & 10 & 11 & 12 & 13 & 14 & 15 & 16 & 17 & 18 & $a^{*}$ \\
\hline $\begin{array}{c}\text { Peptide } \\
\text { no./sequence }\end{array}$ & Pru p 3 & 2.1 & 2,0 & & & & 2,3 & & 2,7 & & 2,0 & 2,9 & 2,2 & & & & & & & 39 \\
\hline 1 & ITCGQVSSSL & & & & & & & & 2,7 & & & & & & 2,1 & 2,9 & & & & 17 \\
\hline 2 & VSSSLAPCIP & & & & & & & & & & & & & & & & & & & 0 \\
\hline 3 & APCIPYVRGG & & & & & & & & & & & & 2.7 & & & & & & & 6 \\
\hline 4 & YVRGGGAVPP & & & & & & & & & 3,1 & & & 2.5 & & & & & & & 11 \\
\hline 5 & GAVPPACCNG & & 2,2 & & & & & & & & 2,0 & & 2,0 & & & & & 2,2 & 2,2 & 28 \\
\hline 6 & ACCNGIRNVN & & 2,2 & & & & & & & 2,2 & & & 2,1 & & & & & 2,4 & & 22 \\
\hline 7 & IRNVNNLART & 2.1 & 2,3 & & & & 3,2 & & & 2,8 & & & 2,0 & & & & & & & 28 \\
\hline 8 & NLARTTPDRQ & & 2,1 & & & & 2,9 & & & & 2,3 & & & 2,4 & & & & & & 22 \\
\hline 9 & TPDRQAACNC & & & & & & & 2,0 & 2,0 & & 2,2 & & & 2,6 & 2.2 & 2,1 & & & & 33 \\
\hline 10 & AACNCLKQLS & 2,0 & & & & 2,8 & 3,5 & 2,3 & & & 2,4 & & & & 2.6 & 2,4 & & & & 39 \\
\hline 11 & LKQLSASVPG & & & & & 2.1 & 2,4 & 2,4 & & & & & 2,0 & & 2,3 & & 2,0 & & & 33 \\
\hline 12 & ASVPGVNPNN & 2,2 & & 2,0 & & 2,8 & & & & & & & 2,2 & & 2,3 & & 2.3 & 2,3 & 2,0 & 45 \\
\hline 13 & VNPNNAAALP & 2,4 & & & 2,2 & & & & & 2,4 & & & 2,4 & & & & & 3.1 & 2,4 & 33 \\
\hline 14 & AAALPGKCGV & 3,0 & & & & 3,3 & 2,6 & & & 2,3 & & 2,0 & 4,0 & & 2.5 & & 2,7 & 83 & 9,8 & 56 \\
\hline 15 & GKCGVSIPYK & 3,8 & 2,4 & & & 3,3 & 3,0 & 2,6 & & & & & 2,3 & 2,4 & 2,3 & & 2.6 & & 2,9 & 56 \\
\hline 16 & SIPYKISAST & & & & & 3,9 & 2.5 & & & & & & & 2,1 & 2,8 & & & & 2,5 & 28 \\
\hline 17 & ISASTNCATVK & & & 2,3 & & 2,9 & 3,2 & & & & & & & & & & & & & 17 \\
\hline
\end{tabular}

\begin{tabular}{|l|l|l|l|l|l|l|l|l|l|}
\hline $\mathbf{6}$ & $\mathbf{7}$ & $\mathbf{8}$ & $\mathbf{9}$ & $\mathbf{1 0}$ & $\mathbf{1 1}$ & $\mathbf{1 2}$ & $\mathbf{1 3}$ & $\mathbf{1 4}$ & $\mathbf{6}$ \\
\hline 3,8 & 3,1 & 3,4 & 3,1 & 3,1 & 3,5 & 3,1 & 3,5 & 3,1 & $\mathbf{1 0 0}$ \\
\hline & 3,6 & 3,1 & & & & & & & 22 \\
\hline & & & & & & & & & 0 \\
\hline & & & & & & & & & 0 \\
\hline & & & & & & & & & 0 \\
\hline & 3,3 & & & & & & & 3,5 & 22 \\
\hline & 3,0 & & 3,7 & & 3,5 & 3,2 & 4,0 & 3,5 & 67 \\
\hline & 5,9 & & 3,4 & & & & & & 22 \\
\hline & 3,1 & & 3,8 & & & & & & 22 \\
\hline 3,0 & 3,6 & & 3,8 & & & & & & 33 \\
\hline & & & & & & & & 3,3 & 11 \\
\hline & & 3,2 & & & 3,3 & & & 3,3 & 33 \\
\hline & & & & & & & & 3,7 & 11 \\
\hline & 5,1 & & & & 3,7 & & 3,1 & 3,1 & 4 \\
\hline & 5,5 & & 3,5 & 3,9 & & 4,0 & 3,7 & & $\mathbf{5 6}$ \\
\hline & 3,6 & 3,1 & 3,5 & 3,2 & 3,5 & & 3,7 & & 67 \\
\hline & & & 3,7 & 3,0 & & & & 3,1 & 33 \\
\hline & & & 3,2 & 3,0 & & & & & 22 \\
\hline
\end{tabular}

$\mathrm{ASI} \geq 2$ for PBMCS and $\mathrm{SI} \geq 3$ for TCLS was considered positive. " $a$ and $b$ are the frequency (\%) of positive responses to Pru p 3 or to each peptide for PBMCs or TCLs, respectively. 


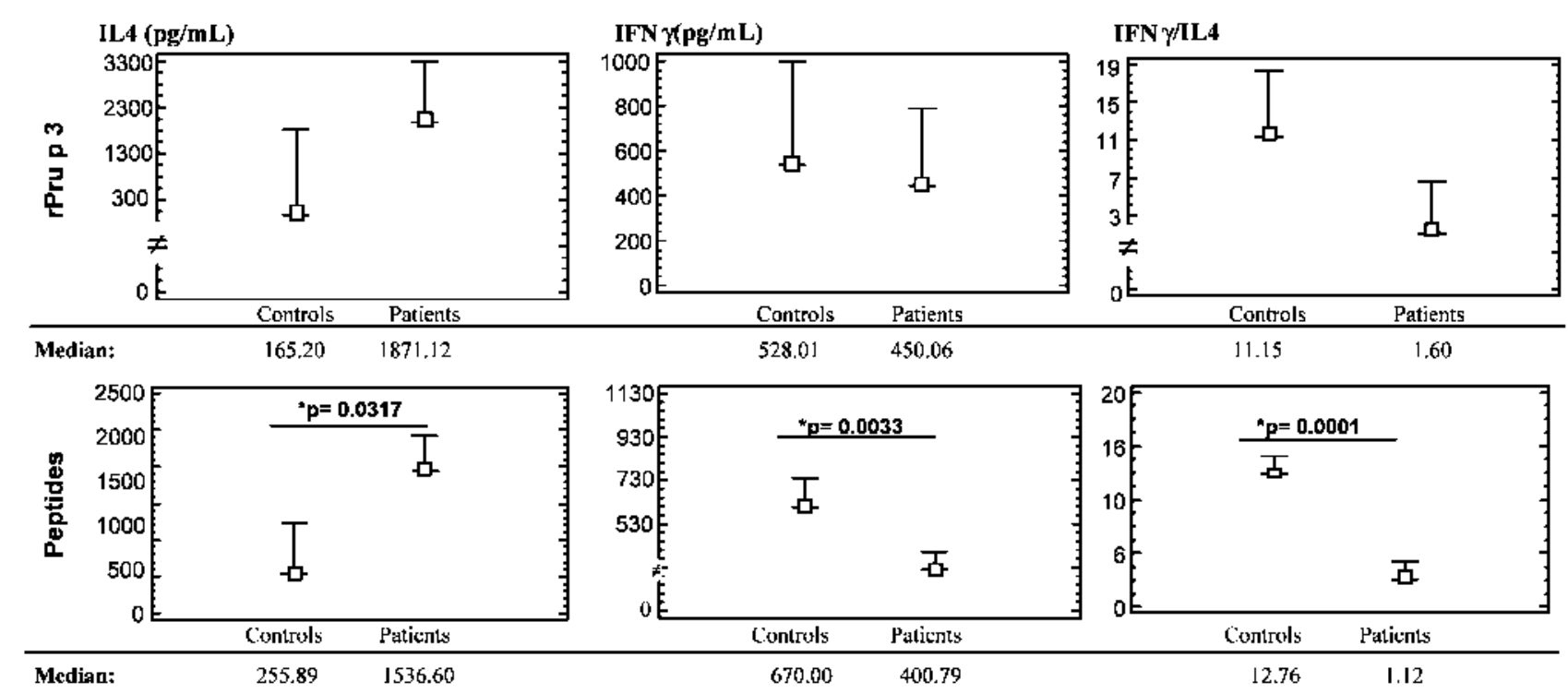

Fig. 3. Location on the 3-D structure of Pru p 3 of T-cell epitopes Pru p 325-35 (blue) and Pru p 365-8n (green). (A) Amino acid sequence of Pru p 3, temarking the T-epitopes described in the present study. (B) Ribbon diagram showing amino acid side chains. The labels denote the four helices and $C$ terminus. (C) Molecular surface (wireframe) showing the areas covered by the T-cell epitopes (solid) at the orientation in $B$.

be considered as a single T-cell epitope: Pru p $365-80$. The rest of peptides developed positive responses from $45 \%$ to $0 \%$ of PBMCs (Table 1). A similar pattern was found in the control group for most of the synthetic peptides, except for peptide 10 (Fig. 2, PBMCs), which provoked stimulation ( $\mathrm{SI} \geq 2$ ) in $70 \%$ of control subjects, but only in $39 \%$ of PBMCs from patients. In spite of the statistical significance of this difference $(p=0.0083)$, the number of non-peach allergic subjects analyzed should be increased to define Pru p $345-55$ (peptide 10) as a non-allergic T-cell epitope. On the other hand, Pru p $365-80$ (peptides 14 and 15 ) was also recognized by approximately 90\% of PBMCs from control subjects.

TCLs were produced by a long-time culture with Pru p 3 of PBMCs from nine patients and five controls subjects. Their proliferative response induced by the full allergen and its derived peptides are summarized in Table 1 (TCLs) and Fig. 2 (TCLs). The quantitative response was similar in both groups (patients, mean: $8813 \mathrm{cpm}$, range: $2493-30,304 \mathrm{cpm}$, background: $1048 \mathrm{cpm}$; controls, mean: $9120 \mathrm{cpm}$, range: $1232-41,638 \mathrm{cpm}$, background: 1253 ), as well as the T-cell phenotype, which showed the same CD4+/CD8+ ratio (65\%/35\%). In contrast with the behaviour exhibited by PBMCs, all the patients' TCLs were activated by Pru p $3(100 \%)$, while only $20 \%$ were activated in control subjects.

Two main T-cell epitopes were identified analyzing the TCLS from patients: Pru p $3_{65-80}$ ( $\mathrm{Sl}>3$ in $78 \%$ of lines), previously located in the screening of PBMCs, and Pru p $3_{25-35}$ by TCLs and PBMCs $(67 \%$ versus $22 \%$ ), indicated a higher specificity and a lower activity than Pru p 365-80. The latter also stimulated all five TCLs from control subjects, which were also activated by Pru p $330-40$ (peptide 7) and Pru p 350-60 (peptide 11) in four out of five (80\%) samples. Interestingly, peptide 7 is contiguous and shares 5 amino acid residues with Pru p $325-35$, the second T-cell epitope identified by analysis of TCLs from patients (see above). The same is true for peptide 11 with respect to Pru p $3_{45-55}$ (peptide 10), which had the highest stimulation rate to PBMCs from control subjects.

Both of major T-cell epitopes of Pru p 3 were located on the 3-D structure of the peach allergen (Fig. 1) in the immediate vicinity of the lgE-binding regions described before (Garcia-Casado et al., 2003; Pacios et al., 2008). Pru p $325-35$ spans virtually all the helix $\mathrm{H} 2$ (25-36) and hence, it shows alternating buried and exposed residues. Pru $\mathrm{p} 365-80$ spans part of helix $\mathrm{H} 4(63-73)$ and a large seg- ment of the C-terminal coil (74-91). Contrarily to Pru p 325-35, the latter T-cell epitope is mostly composed of exposed residues even though it shows predominance of hydrophobic amino acids. However, four residues (A66, L69, 177, and Y79) are almost completely buried.

\subsection{IL4 and IFNy levels in TCL cultures indicate a differential type of T-cell response to Pru $\mathrm{p} 3$ in patients and control subjects}

Supernatants of TCL cultures treated with Pru p 3 or its derived peptides were recovered to quantify the production of IL4 and IFN $\gamma$, used as molecular markers of a Th2 or Th1 response, respectively (Fig. 3). Patients' TCLs produced mainly IL4, with an IFN $\gamma /$ IL4 ratio lower than 2. In contrast, control subjects yielded a high amount of IFN $\gamma$ and an IFN $\gamma /$ IL4 ratio higher than 11. These differences between patients and controls were non-statistically significant for Pru p 3, probably due to the limited number of samples analyzed, but were clearly significant $(p<0.05)$ for both IL4 and IFN $\gamma$ levels, as well as the IFN $\gamma /$ IL4 4 ratio, considering the pooled data observed in TCL cultures stimulated with each synthetic peptide (Fig. 3). This scenario was further confirmed by the analysis of cytokine levels in TCL supernatants treated with Pru p 3 (Table 2), indicated a Th2 type response in most patients, and a Th1 type in most control subjects. A Th0 response was detected in two cases from each the patient and control group.

\section{Discussion}

Allergies are on the rise, becoming an important health problem in western countries. Over $25 \%$ of the population suffers from IgEmediated allergic symptoms (Burks and Ballmer-Weber, 2006). The search of new tools for diagnosis and treatment would improve the life-quality of patients. In the last decade, new concepts of specific immunotherapy have evolved based on recombinant expression of allergens. Hypoallergenic isoforms or mutants with reduced lgEbinding capacity would enable the use of a specific, safer and more efficient immunotherapy in the future (Woodfolk, 2007; Wagner et al., 2008).

The involvement of CD4+ T-lymphocytes in the hypersensitive type I reactions is well established (Abbas et al., 1996; Thomas et 
Table 2

IL4 and INFy levels in TCL supernatants from patients and control subjects after stimulation witl rPtu p 3 Cytokine.

\begin{tabular}{lccl}
\hline Cytokine production & & & \\
\hline TCL derived ftom: & IFN- $\gamma(\rho g / \mathrm{ml})$ & ILA $(\rho \mathrm{g} / \mathrm{ml})$ & Tli subset $^{\mathbf{b}}$ \\
\hline Patient 6 & 40 & 2,500 & 2 \\
Patient 7 & 200 & 3,000 & 2 \\
Patient 8 & 50 & 2,000 & 2 \\
Patient 9 & 300 & 2,000 & 2 \\
Patient 10 & 2200 & 10,000 & 2 \\
Patient 11 & 800 & 1,000 & 2 \\
Patient 12 & 50 & 50 & 0 \\
Patient 13 & 110 & 3,000 & 2 \\
Patient 14 & 300 & 40 & 0 \\
Cont rol 3 & 1100 & 26 & 1 \\
Cont nol 4 & 1600 & 150 & 1 \\
Cont nol 5 & 5000 & 700 & 1 \\
Cont nol 6 & 340 & 100 & 0 \\
Cont nol 7 & 100 & 50 & 0 \\
\hline
\end{tabular}

\section{a Means $(n=3)$.}

b All INFy JILA ratio > 10, from 2 to 10 , and $<2$ was considered a Th1, Tho, and Th2 response, respectively.

al., 2004). T-cells also contribute to induce tolerance to specific immunotherapy. During the vaccination process, a typical allergic Th2 response changes to a Th1, and, finally, a suppression of allergen-specific T-cell responses has been observed (Bohle, 2006, 2007; Woodfolk, 2007). Evaluation of immunotherapies using peptides is generating great expectations. The challenge with T-peptide epitopes would result in stimulation of the T-cells, but no activation of mast cells and basophiles (Haselden et al., 2001; Smith and Larche, 2004). The refore, it seems crucial to identify the dominant T-cell epitopes of the major peach allergen Pru p 3 , in order to develop a T-cell targeted vaccine to be used for allergic patients to this fruit.

The aim has been approached by proliferation assays of PBMCs and TCLs from clinically verified peach-allergic patients sensitized to Pru p 3. These PBMCs exhibited a moderate Pru p 3-specific activation (39\%). This low-cellular response could be explained as a result of suppression mediated by immunoregulatory mechanism (Zeiler et al., 1999; Glaspole et al., 2005). However, a further step selecting Pru p 3-specific TCLs from some of the same patients, rendered CD4+ T-cell clones, most with a Th2 cytokine profile, and all of them activated by Pru p 3. Taking into account the results of the whole set of proliferation assays testing the synthetic peptides which covered the full Pru $\mathrm{p} 3$ amino acid sequence, two T-cell epitopes have been uncovered. Pru p $3_{65-80}$, defined by two consecutive immunodominant peptides, emerged as a major epitope recognized by $72 \%$ of PBMCs and over $78 \%$ of TCLs from patients. Pru p 325-35 represents a second T-cell epitope, pointed out exclusively by TCLs ( $67 \%$ of positive responses). Remarkably, both sequential regions are localized in the 3-D structure of the peach allergen near its lgE epitopes previously described (Garcia-Casado et al., 2003; Pacios et al., 2008). Thus, Pru p $365-80$ overlaps a conformational [gE epitope (Pacios et al., 2008), whereas Pru p 325-35 covers the first sequential (positions 23-36) epitope identified by Garcia-Casado et al. (2003). Pru p 325-35 comprises alternating buried and exposed residues, whereas Pru p 365 -80 mostly faces the clashes with the solvent spite its hydrophobic residue predominance. However, the significance of buried residues in both T-cell epitopes suggests that sequential issues instead of precise surface location might be more important in the activation of the T-cell response.

Interestingly, the analysis of PBMCs and TCLs from 10 control volunteers without peach allergy non-sensitized to Pru $\mathrm{p} 3$, roughly detected the same reactive synthetic peptides than those described above for the patient group. Pru p $3_{65-80}$ was the more active sequential region activating PBMCs and TCLs from the control group, and a second active amino acid region, Pru p 330-40, overlaps with the second T-cell epitope localized when assaying patients' TCLs. Additionally, Pru p 350-60 was recognized by control subjects, but not by PBMCs or TCLs derived from patients. Potential T-cell epitopes of other allergens, such as Art v 1 and Bet v 1 , have been reported to also stimulate T-cell from both patients and control subjects (Ebner et al., 1995; Haselden et al., 2001; JahnSchmid et al., 2002; Glaspole et al., 2005). This fact suggests that the switch to allergic tolerance must not operate in the antigen-T-cell recognition, but in a subsequent step. A higher IFN $\gamma /$ IL 4 ratio was observed in the controls in comparison with the patients' results. The majority of allergen-specific TCls derived from allergic individuals displayed a Th2-like pattern of cytokine production, while non-allergic TCLs showed a Th1-like pattern of cytokines. This difference could explain the response of controls versus patients: since the former could tolerate Pru p 3, the latter would react by inducing an allergic response (Schade et al., 2000; Turcanu et al., 2008). The difference in cytokine responses between control and peachallergic subjects does not seem to be based on different genetic backgrounds, because TCLs from both groups displayed a similar CD4+/CD8+ rate, and two control individuals allergic to grass pollen (control 5 and control 7 in Table 2) showed a Th 1 and Th0 response, respectively, according to their IFN $\gamma /$ IL4 ratio.

Summarizing, a limited number of T-cell epitopes are present in the peach allergen Pru p 3, the sequential Pru p 365-80 being particularly relevant. These epitopes lead to activation of different Th subtypes in patients (Th2- response) and in peach non-allergic control subjects (Th1- response). The characterization of T-cell epitopes has implications for future developments in specific immunotherapy for type l allergy. The immunodominant T-cell epitope identified in Pru p 3 may be a suitable candidate for peptide treatment of peach allergy.

\section{References}

Abbas, A.K, Murphy, K.M., Sher, A., 1996. Functional diversity of helper T lymphocytes. Nature 383, 787-793.

Bohle, B., 2006. T-cell epitopes of food allergens. Clin. Rev. Allergy Immunol. 30. 97-108.

Bolile, B., 2007. The impact of pollen-felated food allergens on pollen allergy. Allergy 62, 3-10.

Butks, W., Ballmet-Weber, B.K,, 2006. Food allergy, Mol. Nutt, Food Res, 50, 595-603. Cuesta-Herranz,J., Lazaro, M., de las Heras, M., Luch, M., Figueredo, E., Um pierrez, A., Hernandez, J., Cuesta, C., 1998. Peach allergy pattern: experience in 70 patients. Allergy 53, 78-82.

Cuesta-Herranz, J., Lazaro, M. Martinez, A., Figueredo, E., Palacios, R. de las Hecas, M., Mart inez, J., 1999. Pollen allergy in peach-allergic patients; sensitization and cross-reactivity to taxonomically unrelated pollens. J. Allergy Clin. Immunol. $104,688-694$.

Diaz-Perales, A. Lombardero, M., Sanchez-Monge, R., Garcia-Selles, F.J., Pernas, M., Fernandez-Rivas, M., Barber, D., Salcedo, G., 2000. Lipid-transfer proteins as potential plant panallergens; cross-reactivity among proteins of Artemisio pollen, Castanea nut and Rosaceae fruits, witl different IgE-binding capacities. Clin. Exp. Allergy 30, 1403-1410.

Diaz-Perales, A., Sanz, M.L., Garcia-Casado, G., Sanchez-Monge, R., Garcia-Selles, FJ., Lombardero, M., Polo, F., Gamboa, P.M., Barber, D., Salcedo, G., 2003. Recombinant Pח p 3 and natural PחI p 3, a major peach allergen, show equivalent immunologic reactivity: a new tool for the diagnosis of truit allergy. J. Allergy Clin. Immunol. 111, 628-633.

EAACI, Subcomittee of Skin Tests and Allergen Standardization, 1989. Skin tests tor diagnosis of $\mathrm{gE}$-mediated allergy. Allergy 44, 31-37.

Ebner, C., Hirschwehr, R., Bauer, L., Breiteneder, H., Valenta, R., Ebner, H., Kraft, D., Scheiner, $0_{\text {. }}$ 1995. Identification of alletgens in truits and vegetables: IgE crossreactivities with the important birch pollen allergens Bet $v 1$ and Bet v 2 (birch profilin). J. Allergy Clin. Immunol. 95, 962-969.

Fernandez-Rivas, M., Gonzalez-Mancebo, E., Rodriguez-Perez, R., Benito, C., SanchezMonge, R., Salcedo, G., Alonso, M.D., Rosado, A., Tejedor, M.A., Vila, C., Casas, M.L., 2003. Clinically relevant peach allergy is related to peach lipid transfer protein, Pru p 3, in the Spanish population. I. Allergy Clin. Immunol. 112, 789-795.

Garcia-Casado, G., Pacios, L.F., Diaz-Perales, A., Sanchez-Monge, R., Lombardero, M., Garcia-Selles, F.J., Polo, F., Barber, D., Salcedo, G., 2003. Identification of lgEbinding epitopes of the major peach allergen Pri p 3. J. Allergy Clin. Immunol. $112,599-605$. 
Glaspole, I.N., de Leon, M.P., Rolland, J.M. o'Hehir, R.E., 2005 . Characterization of the T-cell epitopes of a major peanut allergen Ara h 2, Allengy 60, 35-40.

Haselden, B.M., Syrigou, E., Jones, M., Huston, D., Ichikawa, K., Chapman, M.D. Kay. A.B., Larche, M., 2001. Proliteration and release of IL-5 and IFN-gamma by peripheral blood mononuclear cells from cat-allergic asthmatics and rhínitics, non-cat-allergic asthmatics, and normal controls to peptides derived from Fel d 1 chain 1. J. Allergy Clin, Immunol, 108, 349-356.

Jahn-Schmid, B., Kelemen, P., Himly, M., Bohle, B., Fischer, G., Ferreira, F., Ebner, C., 2002. The T cell response to Art $\vee 1$, the major mugwort pollen allergen, is dominated by one epitope. I. Immunol. 169, 6005-6011

Kanny, C., Moneret-Vaut rin, D.A., Flabbee, J., Beaudouin, E., Morisset, M., Thevenin, $\mathrm{F}, 2001$. Population study of food allergy in Fiance. J. Allergy Clin. Immunol, 108 , 133-140.

Laurer, I., Miguel Moncin, M., Abel, T., Foetisch, K., Hartz, M., Fortunato, D., et al., 2007. Identification of a plane pollen lipid transfer ptotein (Pla a 3) and its immunological relation to the peach lipid transfer protein Pru p 3. Clin. Exp. Allergy 37. 261-269.

Lombatde to, M., Garcia-Selles, F,J., Polo, F, Jimeno, L, Chamotro, M, J., Garcia-Casado, G., Sanchez-Monge, R., Diaz-Perales, A., Salcedo, G., Barber, D., 2004. Prevalence of sensitization to Artemisla allergens Ait $v 1$ Att $v 3$ and Art $v 60 \mathrm{kDa}$, Cross reactivity among Art $v 3$ and other relevant lipid-transfer protein allergens. Clin. Exp. Allergy 34, 1415-1421.

Pacios, L.F., Tordesillas, L., Cuesta-Herranz, J., Compes, E, Sanchez-Monge, R, Palacin A., Salcedo, G., Diaz-Perales, A., 2008. Mimotope mapping as a complementary strategy to define al lergen lgE-epitopes: peach Pru $p 3$ allergen as a model. Mol. Immunol. 45, 2269-2276.

Pasquato, N., Berni, R., Folli, C., Folloni, S., Cianci, M., Pantano, S., Helliwell, J.R., Zanotti, G. 2006. Crystal structure of peach Pru 03 , the prototypic member of the family of plant non-specific lípid transfer protein pan-allergens. J. Mol. Biol. 356 , 684-694.

Salcedo, G. Sanchez-Monge, R., Batbet; D., Diaz-Perales, A., 2007. Plant non-specitic lipid transfer proteins: an interface between plant defence and human allergy. Biochim. Biopliys. Acta 1771, 781-791.
Sanchez-Monge, R Lombardero, M Garcia-Selles, FJ Barber, D. Salcedo, G., 1999. Lipid-transfer proteins ate televant alletgens in fruit allergy. J. Allergy Clin. Immunol. 103, 514-519.

Schade, R.P., Van leperen-Van Dijk, A.G., Van Reijsen, F,C., Versluis, C. Kimpen, J.L, Knol, E.F., Bruijnzeel-Koomen, C.A., Van Hoffen, E., 2000. Differences in antigenspecific T-cell responses between IFNants with atopic dermatitis with and without cow's milk allergy: relevance of Th2 cytokines. J. Alletgy Clin. Immunol. $106,1155-1162$

Smit li, T.R., Larche, M. 2004. Investigating T cell activation and tolerance in vivo: peptide clallenge in alleryic asthmatics. Cytokine $28,49-54$.

Tanabe, S., 2007. Epitope peptides and immunotherapy. Curc. Protein Pept. Sci. 8 $109-118$.

Thomas, W.R., Hales, B.J., Smith, W.A., 2004 . Recombinant allergens for analysing T-cell responses. Methods 32, 255-264.

Turcanu, V., Winterbotham, M., Kellehet, P., Lack, G., 2008. Peanut-specific B and T cell responses are correlated in peanut-allergic but not in non-allergic individuals. Clin. Exp. Allergy 38, 1132-1139.

van Ree, R, 2002. Clinical importance of non-specific lipid transfer proteins as tood allergens. Biochem. Soc. Trans, 30, 910-913.

Wagner, S. Radauer, C., Bublin, M., Hoffmanı-Sommeryruber, K., Kopp, T. Greiseneg ger, E.K., Vogel, L., Vieths, S., Scheiner, O., Breiteneder, H., 2008. Naturally occurring hypoallergenic Bet $v 1$ isoforms fail to induce lgE responses in individuals with birch pollen allergy. J. Allergy Clin. Immunol. 121, $246-252$.

Woodfolk, J.A, 2007. T-cell tesponses to allergens. J. Alletgy Clin. Immunol, 119 $280-294$.

Zeiler, T., Mantyjarvi, R., Rautiainen, J., Rytkonen-Nissinen, M., Vilja, P., Taivainen, A. et al, 1999. T cell epitopes of a lipocalin al lergen colocalize with the conserved regions of the molecule. J. Immunol. 162, 1415-1422.

Zuidmeer, L, van Ree, R, 2007. Lipid transter potein allergy: primary food allergy or pollenffood syndrome in some cases. Curt, opin. Allergy Clin. Immunol. 7 . $269-273$ 